\title{
Afterword: 6400 Kilometres Away-But Not a Policy World Apart
}

\section{Elana Wilson Rowe and Helge Blakkisrud}

\begin{abstract}
The Afterword presents two key findings from this volume. First, while numerous new strategy documents and instruments have been adopted in recent years, contributing authors voice concern about the steps Moscow has taken to translate lofty ideas into practical policies. Second, the key initiatives were formulated well before the current crisis in Russia's relations with the West. While a certain rebalancing of the Western and Eastern vectors is taking place, there is still a long way to go before Russia's 'window to the East' can match its 'window to the West'. Only long-term commitment on the part of Moscow can transform the Russian Far East from a neglected periphery and military outpost into a viable gateway to the Asia-Pacific.
\end{abstract}

Keywords Russia - Russian Far East • Crimean conflict • Asia-Pacific region • Policymaking

\section{E.W. Rowe $(\bowtie)$}

Research Group on Emerging Powers and Global Development, Norwegian Institute of International Affairs, Oslo, Norway

H. Blakkisrud

Research Group on Russia, Eurasia and the Arctic, Norwegian Institute of International Affairs, Oslo, Norway

(C) The Author(s) 2018

H. Blakkisrud, E. Wilson Rowe (eds.), Russia's Turn to the East, Global Reordering, https://doi.org/10.1007/978-3-319-69790-1_9 
More than 6400 kilometres separate Vladivostok from Moscow. As the contributions to this volume have demonstrated, being located in a different part of the world from Moscow does matter for how the Russian Far East is developing, and how Russia's connections to the broader AsiaPacific region are evolving. With its status as a potential 'bridge to Asia', the Russian Far East attracts important federal-level attention-together with a specific set of security concerns.

And yet, some challenges are shared across this geographical vastness. For example, the Russian economy's overwhelming reliance on international natural resource markets remains a challenge for all parts of the country. The collapse of the oil price in 2014, exacerbated by the international sanctions regime imposed after Russia's annexation of Crimea, has brought worsened economic outlooks. In general, growth-or lack thereof-in the Russian Far East tallies with the average of the Russian economy overall. However, as pointed out in Chap. 4, compared to the economic powerhouse regions around Moscow and St Petersburg, the Russian Far East has been lagging far behind and the Far Eastern Federal Okrug remains the second smallest economy among Russia's eight federal okrugs.

In this brief Afterword, we return to two key sets of findings from the preceding chapters. These findings concern the nature of Russia's 'turn to the East' thus far and the prospects for tackling the political and economic challenges that have long hampered regional development.

\section{Pivoting, Turning or Leaning? A Growing Suite of Measures and Institutions}

The chapters in this volume have presented the new policy documents and instruments designed to accelerate the economic development of the Russian Far East and strengthen diplomatic connections and trade relations in the broader Asia-Pacific region. A significant point of variation across these efforts and policies is the extent to which they have realizedor seem suitable for realizing - the stated policy aims. While noting that it is still too early to judge what the ultimate outcome of Russia's greater emphasis on its Far East will be, many contributing authors voice concern about some of the first steps Moscow has taken towards translating lofty policy ideas into practical policies.

Concerning the institutional level, Helge Blakkisrud (Chap. 2) notes that a new development model centred around the institutionally innovative, partially decentralized Ministry for the Development of the Far East 
has been anchored in federal-regional politics. The question remains, however, whether this new model will be capable of generating and implementing policy solutions to the challenges the Russian Far East is facing. Old habits of top-down approaches seem to persist, and bureaucracy has multiplied in overlapping fashion around the newly created regional development instruments.

As regards the economy, it is probably more fruitful to think of Russia's economic growth plans and policy stimuli for the Russian Far East as efforts to realize the untapped potential of the region, rather than as alternatives to relations with Europe (although diversifying may be a very real and economically healthy goal). A series of economic incentivesmost importantly, the advanced special economic zones (ASEZs) and the free port regime-have been adopted in order to stimulate regional growth, introducing new framework conditions for local and regional development. These changes include new patterns of governance, favourable tax regimes and special financing available for infrastructure development. However, as pointed out by Jiyoung Min and Boogyun Kang (Chap. 4), the ASEZs are in some ways too blunt an instrument: The plans for economic development zones would have benefitted from being more closely connected to or targeted towards potential markets and investors in East Asia. Similarly, Roman Vakulchuk (Chap. 8) notes that the Russian Far East has failed to develop a business climate attractive to foreign investors - 90 per cent of investment in the region still comes from Russian domestic sources. Tamara Troyakova (Chap. 3) voices concern about the lack of coordination among various branches of the government and the new institutions they have set up to facilitate economic development.

Efforts at economic development in the Russian Far East have yet to bear fruit. Several contributing authors argue that it will still take some time before we can see the full potential of the upgrade of the regional infrastructure that is underway. An important consideration here is the broader economic picture: How might federal budgetary constraints play a role? There is already concern about the level of financing that will be available to the newly established regional economic development mechanisms. Non-state contributions, foreign direct investment in particular, have remained negligible; and the number of potential investors has been limited by the European- and North American-supported sanctions regime in place at the time of writing. 
As regards international diplomacy, many chapters discuss whether China and Russia will succeed in deepening their bilateral relations, with their shared positioning in the Asia-Pacific region as an anchor point. In Chap. 7, Marc Lanteigne, analysing Sino-Russian relations through the prism of the Shanghai Cooperation Organization (SCO), argues that the China-Russia relationship is constrained by diverging viewpoints on several key issues, especially relating to global politics, and different status positions within international relations (China as a major rising power, Russia as a declining one). Looking more specifically at energy relations, Indra Overland and Gulaikhan Kubayeva (Chap. 6) argue that the relationship remains a marriage of convenience, primarily around energy interests, that could either deepen or fade with time. Malin Østevik and Natasha Kuhrt (Chap. 5) link diplomatic ambitions to security thinking and classify Russia as a 'bystander' in the Asia-Pacific region. They argue that the underdevelopment of the Russian Far East has caused the region to be seen as a security risk, generating a securitized approach that has hindered Russia's aspirations for domestic economic development in the Russian Far East and effective regional diplomacy.

\section{Turning as Turning Away? Europe or Asia in a Post-Crimea Period}

Contributing authors have also considered whether the diplomatic and economic consequences of Russia's annexation of Crimea and involvement in Eastern Ukraine in 2014 have affected policies and practices towards the Russian Far East and the broader Asia-Pacific region. We bring together some of those observations here, with the cautionary note that simultaneity should not, of course, automatically be taken to imply causality.

Post 2014, Vakulchuk notes that the Russian Far East's trade with Asian partners has contracted, and suggests that expanding these relations would be easier in a non-sanctions scenario. Likewise, Min and Kang note that it has been challenging for Russia to balance openness to the East Asian region against its politically driven import substitution policy.

Looking at energy projects, Overland and Kubayeva argue that, by and large, post-Crimea cooperation with China on such projects has generally been a continuation of already established trends. Moscow presented the May 2014 deal on the construction of the Power of 
Siberia gas pipeline as a major success of diplomacy and a sign of the strong Sino-Russian bilateral relationship. In this specific instance, the authors note, talks were expedited and intensified in 2014. That same year, exports of oil from Russia to China increased by 36 per cent. However, the failure to reach agreement on the Vankor project, where the Chinese were replaced by new Indian partners in 2016, shows the limits of the political willingness to develop bilateral relations with China at any cost.

Østevik and Kuhrt find little concrete change in Russian security policy towards the wider region, with important driving forces for security thinking and engagement in the Russian Far East and broader Asia-Pacific region being established long before 2014 and pursued with few interruptions. A key difference, however, has been the intensified high-political and diplomatic attention to the Sino-Russian bilateral relationship. Still, as also noted by Lanteigne in his chapter on the SCO, Russia's deteriorating relations with the West have made the Sino-Russian bilateral relationship complex. Lanteigne argues that China has resisted Russia's interest in expanding the security/military aspects of the SCO, seeking instead to broaden the portfolio by including economic development questions and new investment opportunities for Chinese capital in Central Asia. On the specific topic of Russia's annexation of Crimea, China has avoided making any statement of support or condemnation, and in the UN Security Council, China chose to abstain rather than joining Russia in exercising its veto power.

The main conclusion to be derived from these chapters is that the key policy initiatives aimed at developing the Russian Far East were formulated well before the onset of the current crisis in Russia's relations with the West. However, the post-2014 breakdown seems to have added an element of urgency to Russia's 'turn to Asia', as witnessed in the heightened level of diplomatic celebrations around successfully concluded cooperation with the countries of the Asia-Pacific region.

When it comes to realizing Moscow's ambitious plans, however, perhaps the most urgent element is financial. As both Blakkisrud and Troyakova point out, despite the public fanfare, the post-Crimea period has been marked by a steady decline in the scope of state involvement in the Russian Far East. From the peak that accompanied the adoption of 
Minister of Far Eastern Development Viktor Ishaev's grandiose state programme in 2013, state funding and promises have been cut back, year after year. These budget cuts may be the product of heavy pressure on limited resources - the fall in the oil price and the effects of the sanctions regime have forced the government to introduce austerity measures. However, even if the cuts do not reflect an actual de-prioritization of Moscow's pivot to the East, they might serve to undermine and obstruct realization of the policy aims that inspired the pivot in the first place.

While a certain rebalancing of the Western and Eastern vectors is clearly taking place, there is still a long way to go before Russia's 'window to the East' can match its 'window to the West'. Only long-term commitment on the part of Moscow can transform the Russian Far East from a neglected periphery and military outpost into a viable gateway to the Asia-Pacific.

Open Access This chapter is licensed under the terms of the Creative Commons Attribution 4.0 International License (http://creativecommons.org/licenses/ by $/ 4.0 /)$, which permits use, sharing, adaptation, distribution and reproduction in any medium or format, as long as you give appropriate credit to the original author(s) and the source, provide a link to the Creative Commons license and indicate if changes were made.

The images or other third party material in this book are included in the book's Creative Commons license, unless indicated otherwise in a credit line to the material. If material is not included in the book's Creative Commons license and your intended use is not permitted by statutory regulation or exceeds the permitted use, you will need to obtain permission directly from the copyright holder.

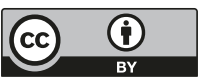

